\title{
Front Matter: Volume 10429
}

, "Front Matter: Volume 10429," Proc. SPIE 10429, Lidar Technologies, Techniques, and Measurements for Atmospheric Remote Sensing XIII, 1042901 (14 December 2017); doi: 10.1117/12.2303924 


\title{
Lidar Technologies, Techniques, and Measurements for Atmospheric Remote Sensing XIII
}

\author{
Upendra N. Singh \\ Doina Nicoleta Nicolae \\ Editors
}

11-12 September 2017

Warsaw, Poland

Sponsored and Published by

SPIE

Cooperating Organisations

Innovation Centre for Sensor and Imaging Systems (United Kingdom)

ADS Scotland (United Kingdom)

The Knowledge Transfer Network (United Kingdom)

Visit Scotland (United Kingdom)

European Regional Development Fund (Belgium)

Technology Scotland (United Kingdom)

European Association of Remote Sensing Companies (Belgium)

European Association of Remote Sensing Laboratories (Germany)

The British Association of Remote Sensing Companies (United Kingdom)

Remote Sensing \& Photogrammetry Society (United Kingdom) 
The papers in this volume were part of the technical conference cited on the cover and title page. Papers were selected and subject to review by the editors and conference program committee. Some conference presentations may not be available for publication. Additional papers and presentation recordings may be available online in the SPIE Digital Library at SPIEDigitalLibrary.org.

The papers reflect the work and thoughts of the authors and are published herein as submitted. The publisher is not responsible for the validity of the information or for any outcomes resulting from reliance thereon.

Please use the following format to cite material from these proceedings:

Author(s), "Title of Paper," in Lidar Technologies, Techniques, and Measurements for Atmospheric Remote Sensing XIII, edited by Upendra N. Singh, Doina Nicoleta Nicolae, Proceedings of SPIE Vol. 10429 (SPIE, Bellingham, WA, 2017) Seven-digit Article CID Number.

ISSN: 0277-786X

ISSN: 1996-756X (electronic)

ISBN: 9781510613225

ISBN: 9781510613232 (electronic)

Published by

SPIE

P.O. Box 10, Bellingham, Washington 98227-0010 USA

Telephone +1 3606763290 (Pacific Time) · Fax +1 3606471445

SPIE.org

Copyright @ 2017 , Society of Photo-Optical Instrumentation Engineers.

Copying of material in this book for internal or personal use, or for the internal or personal use of specific clients, beyond the fair use provisions granted by the U.S. Copyright Law is authorized by SPIE subject to payment of copying fees. The Transactional Reporting Service base fee for this volume is $\$ 18.00$ per article (or portion thereof), which should be paid directly to the Copyright Clearance Center (CCC), 222 Rosewood Drive, Danvers, MA 01923. Payment may also be made electronically through CCC Online at copyright.com. Other copying for republication, resale, advertising or promotion, or any form of systematic or multiple reproduction of any material in this book is prohibited except with permission in writing from the publisher. The CCC fee code is $0277-$ $786 \mathrm{X} / 17 / \$ 18.00$.

Printed in the United States of America.

Publication of record for individual papers is online in the SPIE Digital Library.

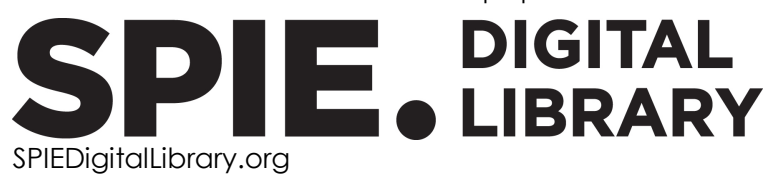

Paper Numbering: Proceedings of SPIE follow an e-First publication model. A unique citation identifier (CID) number is assigned to each article at the time of publication. Utilization of CIDs allows articles to be fully citable as soon as they are published online, and connects the same identifier to all online and print versions of the publication. SPIE uses a seven-digit CID article numbering system structured as follows:

- The first five digits correspond to the SPIE volume number.

- The last two digits indicate publication order within the volume using a Base 36 numbering system employing both numerals and letters. These two-number sets start with $00,01,02,03$, 04, 05, 06, 07, 08, 09, OA, OB ... 0Z, followed by 10-1Z, 20-2Z, etc. The CID Number appears on each page of the manuscript. 


\title{
Contents
}

\author{
$\checkmark$ Authors \\ vii Conference Committee
}

SESSION 1 GREENHOUSE AND TRACE GAS MEASUREMENTS

1042903 New lidar challenges for gas hazard management in industrial environments [10429-2]

1042904 Optical parametric oscillator lidar for the gas constituents sensing in the spectral range of 3-4 $\mu \mathrm{m}[10429-4]$

\section{SESSION $2 \quad$ AEROSOLS, CLOUDS AND WINDS MEASUREMENTS I}

1042906 Strategic positioning of the ERATOSTHENES Research Centre for atmospheric remote sensing research in the Eastern Mediterranean and Middle East region [10429-6]

1042907 Retrieval of microphysical properties of liquid water clouds from atmospheric lidar measurements: comparison of the Raman dual field of view and the depolarization techniques [10429-7]

1042908 Lidar and in situ observations of aerosols, radiation fluxes, and meteorological parameters during the 20 March 2015 solar eclipse over southern Italy [10429-8]

\section{SESSION $3 \quad$ AEROSOLS, CLOUDS, AND WINDS MEASUREMENTS II}

10429 OA Siberian lidar station: the basic complex of remote laser sounding of the atmosphere [10429-10]

10429 OB A graph signal filtering based approach for detection of different edge types on airborne lidar data [10429-12]

10429 OC The vertical correction of point cloud strips performed over the coastal zone of changing sea level [10429-13]

POSTER SESSION

10429 OD Atmospheric lidar co-alignment sensor: flight model electro-optical characterization campaign [10429-15]

10429 OE Space-based lidar for monitoring the Martian canyons [10429-16] 
10429 OG Data processing technique for the all-fiber wind profiler [10429-18]

10429 0J Recovery of wind field characteristics by lidar data [10429-21] 


\section{Authors}

Numbers in the index correspond to the last two digits of the seven-digit citation identifier (CID) article numbering system used in Proceedings of SPIE. The first five digits reflect the volume number. Base 36 numbering is employed for the last two digits and indicates the order of articles within the volume. Numbers start with 00, 01, 02, 03, 04, 05, 06, 07, 08, 09, 0A, 0B...0Z, followed by 10-1Z, 20-2Z, etc.

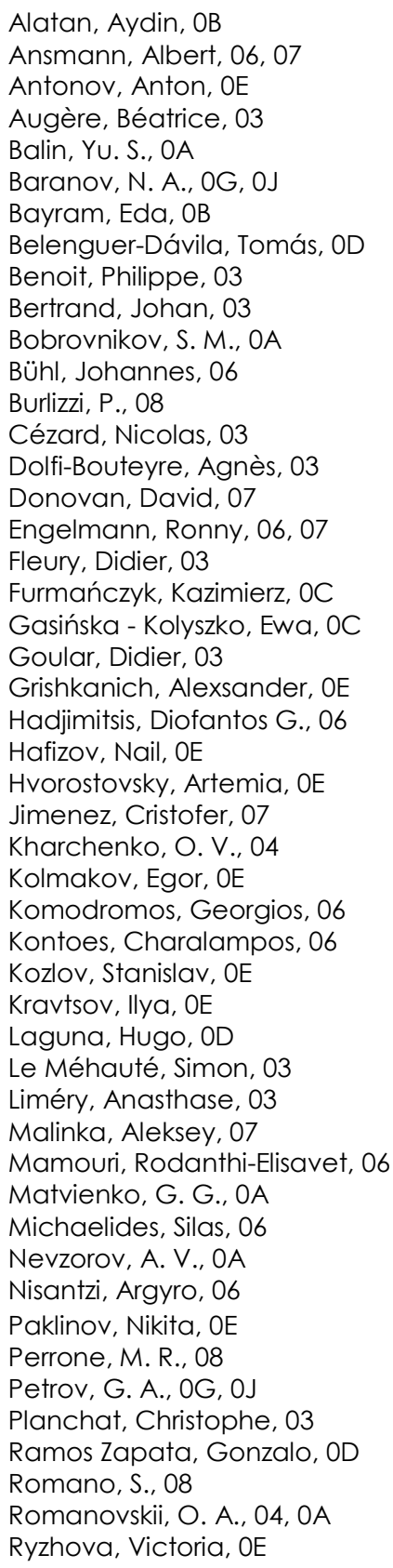

Sadovnikov, S. A., 04

Schmidt, Joerg, 07

Schreier, Gunter, 06

Seifert, Patric, 06

Shiryaev, I. F., OJ

Smirnov, Leonid, OE

Themistocleous, Kyriacos, 06

Valla, Matthieu, 03

Valverde Guijarro, Angel Luis, OD

Vural, Elif, OB

Wandinger, Ulla, 06, 07

Yakovlev, S. V., 04 
Proc. of SPIE Vol. 10429 1042901-6

Downloaded From: https://www.spiedigitallibrary.org/conference-proceedings-of-spie on 26 Apr 2023 Terms of Use: https://www.spiedigitallibrary.org/terms-of-use 


\section{Conference Committee}

Symposium Chair

Klaus Schäfer, (Retired) Karlsruhe Institute of Technology, Institute of Meteorology and Climate Research (Germany)

Symposium Co-chair

Christopher M. U. Neale, University of Nebraska-Lincoln

(United States), Daugherty Water for Food Institute (United States)

Conference Chairs

Upendra N. Singh, NASA Langley Research Center (United States)

Doina Nicoleta Nicolae, National Institute of Research and

Development for Optoelectronics (Romania)

Conference Programme Committee

Arnoud Apituley, Rijksinstituut voor Volksgezondheid en Milieu

(Netherlands)

Lucas Alados-Arboledas, Universidad de Granada (Spain)

Andreas Behrendt, Universität Hohenheim (Germany)

Gerhard Ehret, Deutsches Zentrum für Luft- und Raumfahrt e.V. (Germany)

Barry M. Gross, NOAA-CREST (United States)

Philippe L. Keckhut, LATMOS (France)

George J. Komar, NASA Headquarters (United States)

Eduardo Landulfo, Instituto de Pesquisas Energéticas e Nucleares (Brazil)

Kohei Mizutani, National Institute of Information and Communications Technology (Japan)

Lucia Mona, Istituto di Metodologie per l'Analisi Ambientale (Italy)

Alexandros D. Papayannis, National Technical University of Athens (Greece)

Gelsomina Pappalardo, Istituto di Metodologie per l'Analisi

Ambientale (Italy)

Vincenzo Rizi, Universitá degli Studi dell'Aquila (Italy)

Laurent Sauvage, Leosphere France (France)

Georgios D. Tzeremes, European Space Agency (Netherlands)

Ulla Wandinger, Leibniz Institut für Troposphärenforschung (Germany)

Jirong Yu, NASA Langley Research Center (United States) 


\section{Session Chairs}

1 Greenhouse and Trace Gas Measurements

Upendra N. Singh, NASA Langley Research Center (United States)

2 Aerosols, Clouds and Winds Measurements I

Kyriacos Themistocleous, Cyprus University of Technology (Cyprus)

Eduardo Landulfo, Instituto de Pesquisas Energéticas e Nucleares (Brazil)

3 Aerosols, Clouds, and Winds Measurements II

Kevin B. Strawbridge, Environment and Climate Change Canada (Canada)

Oleg A. Romanovskii, V.E. Zuev Institute of Atmospheric Optics (Russian Federation) 